\title{
EVACUATION OF THE GERMAN POPULATION FROM TRANSNISTRIA IN MARCH-JULY 1944
}

\author{
Vladimir L. Martynenko \\ M.S. Hrushevsky Institute of Ukrainian Archeography and Source Studies \\ of the National Academy of Sciences of Ukraine, Kiev, Ukraine
}

\begin{abstract}
Introduction. During autumn 1943 - spring 1944 the systematic phased evacuation of the German population was carried out from the occupied Soviet regions. Its final phase was the operation of relocating more than 130000 ethnic Germans from the Transnistria Governorate controlled by Romanian authorities to the territory of Warthegau. Materials and methods. The presented research is based on the historicism and objectivity principles. In the course of the work, the author uses special methods such as historical-systematic, chronological, historicaldescriptive, and historical-genetic. The Source base of the research consists of documents of archival funds of Germany, memoirs and partly materials from the German press. Analysis. The decision of the SS leadership to execute the evacuation of ethnic Germans from Transnistria was due to the further advance of Soviet troops in the southern direction. However, even at the planning stage, the German side was faced with serious problems that could disrupt the entire operation. Due to the fact that control over many transport communications was lost, evacuation routes could only run through the territory of Romania, Bulgaria, occupied Serbia and Hungary. Therefore, the German leadership had to initiate urgent negotiations with the authorities of some of these states. Especially difficult was the negotiation process with the Romanian side which did not want to provide any assistance in the evacuation of the Germans from Transnistria. The High Command of the Wehrmacht was also in no hurry to provide assistance (for example, in transport support). Results. Despite the above-mentioned problems, the SS leadership was still able to carry out this resettlement action for several months. Most Germans decided to leave their homes not under the administrative pressure from the occupying authorities, but voluntarily, guided exclusively by the instinct of their survival.
\end{abstract}

Key words: ethnic Germans, evacuation, Germany, Transnistria, Romania, Ethnic German Liaison Office, Sonderkommando "R", Oberkommando der Wehrmacht.

Citation. Martynenko V.L. Evacuation of the German Population from Transnistria in March-July 1944. Vestnik Volgogradskogo gosudarstvennogo universiteta. Seriya 4. Istoriya. Regionovedenie. Mezhdunarodnye otnosheniya [Science Journal of Volgograd State University. History. Area Studies. International Relations], 2020, vol. 25, no. 1, pp. 70-83. (in Russian). DOI: https://doi.org/10.15688/jvolsu4.2020.1.6

\section{ЭВАКУАЦИЯ НЕМЕЦКОГО НАСЕЛЕНИЯ ИЗ ТРАНСНИСТРИИ В МАРТЕ - ИЮЛЕ 1944 ГОДА}

\author{
Владимир Леонидович Мартыненко \\ Институт украинской археографии и источниковедения им. М.С. Грушевского \\ Национальной академии наук Украины, г. Киев, Украина
}

Аннотация. На протяжении осени 1943 - весны 1944 г. из оккупированных советских регионов осуще-
ствлялась планомерная эвакуация немецкого населения. Ее финальной фазой стала операция по переселе-
нию более чем 130000 этнических немцев из находившегося под управлением румынских властей губерна-
торства Транснистрия на территорию округа Вартегау. Решение руководства СС о проведении данной акции
было обусловлено дальнейшим наступлением советских войск на южном направлении. Однако еще на ста- 
дии планирования германская сторона столкнулась с серьезными проблемами, которые могли сорвать всю операцию. В силу того, что контроль над многими транспортными коммуникациями был утрачен, эвакуационные маршруты могли пролегать по территории Румынии, Болгарии, оккупированной Сербии и Венгрии. Поэтому руководству Германии пришлось инициировать срочные переговоры с властями некоторых из этих государств. Особенно сложно протекал переговорный процесс с румынской стороной, которая не желала оказывать какую-либо помощь в эвакуации немцев из Транснистрии. Не спешило оказывать содействие (например, в транспортном обеспечении) и Верховное командование вермахта. Однако, несмотря на эти проблемы, руководство СС все же смогло в течение нескольких месяцев осуществить данную переселенческую акцию. В рамках данной статьи на основе привлечения германских архивных документов и ряда нарративных источников рассмотрены организация и ход эвакуации этнических немцев из Транснистрии на территорию рейха в 1944 году. Отдельное внимание уделено дипломатическим аспектам темы.

Ключевые слова: этнические немцы, эвакуация, Германия, Транснистрия, Румыния, Управление по делам этнических немцев, зондеркоманда «Р», Верховное командование вермахта.

Цитирование. Мартыненко В. Л. Эвакуация немецкого населения из Транснистрии в марте - июле 1944 года // Вестник Волгоградского государственного университета. Серия 4, История. Регионоведение. Международные отношения. - 2020. - Т. 25, № 1. - С. 70-83. - DOI: https://doi.org/10.15688/jvolsu4.2020.1.6

Введение. К концу 1943 - началу 1944 г. для военно-политического руководства Германии стало уже практически очевидно, что натиск Красной армии будет лишь усиливаться. Поэтому в сложившейся ситуации ничего не оставалось, как продолжить акции по добровольно-принудительному перемещению трудоспособного гражданского населения, которое еще проживало на оккупированных советских территориях. Теперь основное внимание германских властей в значительной мере было сосредоточено на южном регионе Украины.

Особенно активный вывоз местного населения из оккупированных районов Николаевской и Одесской областей происходил с января по март 1944 года. Армейское командование, несшее основную ответственность за эвакуацию, старалось пресекать с помощью карательно-репрессивных мер любые попытки саботажа или сопротивления [4, с. 74]. По данным российского исследователя П. Поляна, за 1-й квартал 1944 г. в рейх в общей сложности было отправлено 496244 человека [1, c. 211]. Значительный процент из них составляли те советские граждане, которые по ряду причин эвакуировались добровольно. Одним из таких примеров стала акция по переселению в рейх более 130000 этнических немцев из губернаторства Транснистрия, продолжавшаяся с февраля по июль 1944 года. Данная эвакуация привлекает внимание не только своей массовостью, но и другими отличительными чертами, например организацией и идейно-политической составляющей.
Критерием актуальности темы выступает ее малоизученность не только в привязке к истории немецкого этноса, но и в общем контексте миграционных процессов гражданского населения оккупированных областей СССР в годы Второй мировой войны.

Методы и материалы. Проблема переселения этнических немцев из Транснистрии в рейх в начале 1944 г. еще не получила подробного рассмотрения ни в западной, ни в отечественной историографии. Основной материал по данной теме представлен лишь двумя работами немецких авторов. В первую очередь необходимо отметить небольшую статью Р. Хофмана и ставшую уже фундаментальной монографию И. Флейшхауэр [12; 17]. Однако в этих работах показана лишь общая и довольно сжатая картина проводимой германскими властями эвакуации немецкого населения оккупированного юго-западного региона Украины. Поэтому в них не отражены многие моменты, связанные с организацией и осуществлением данной акции.

Источниковую базу исследования прежде всего составляют документы Федерального архива в Берлине и Архива Института современной истории в Мюнхене. В этот комплекс входят различные директивы, отчеты и сводки Управления по делам этнических немцев (Volksdeutsche Mittelstelle (VoMi); далее ФоМи) и командных структур Вооруженных сил Германии. Немаловажное значение имеют и воспоминания непосредственных участников тех событий, позволяющие детализировать и уточнить ряд аспектов темы. Некото- 
рые сведения были извлечены из материалов германской прессы, в частности таких печатных органов НСДАП, как «Litzmannstädter Zeitung» и «Ostdeutscher Beobachter».

В основе представленного исследования лежат принципы историзма и объективности. В ходе работы активно применялся историкосистемный метод, позволивший раскрыть планирование, механизм и ход эвакуации немецкого населения из оккупированных районов Одесской и Николаевской областей УССР. Параллельно с этим были задействованы такие специальные методы, как хронологический, историко-описательный и историко-генетический. При изучении источников нарративного характера использовался метод контентанализа.

Анализ. По результатам регистрации 1943 г., на территории губернаторства Транснистрия (оккупированный советский регион между Днестром и Южным Бугом), которое с 1941 по 1944 г. находилось под управлением румынской администрации, проживало 130866 этнических немцев. Большинство из них было сосредоточено в сельской местности. Исторически немецкие поселения образовывали четыре крупных анклава: к северу от Тирасполя располагались глюкстальские колонии; между Южным Бугом и Тилигулом березанские колонии; в районе Одессы - кучурганские и крослибентальские колонии. Необходимо отметить, что во время оккупации данного региона этнические немцы обладали особым статусом и на них не распространялась юрисдикция румынских властей. Начиная с августа 1941 г. политико-административный контроль над колонистами осуществляла зондеркоманда «Р» ${ }^{1}$ (структурное подразделение ФоМи) под руководством оберфюрера СС (с 1943 г. бригадефюрера) Х. Хоффмейеpa [28, S. 88-90].

В начале января 1944 г. в связи с неблагоприятным для войск Германии развитием событий на Восточном фронте штаб зондеркоманды «Р», который располагался в колонии Ландау (в то время оккупированная территория Одесской области), впервые задумался о проведении массовой эвакуации немецкого населения из Транснистрии. Однако для ее осуществления предстояло решить ряд важных организационных вопросов. Времени на это было не так много. Проведение будущей акции зависело от переговоров с властями Румынии, так как использовать для перемещения десятков тысяч немецких беженцев многие транспортные магистрали рейхскомиссариата «Украина» уже не представлялось возможным. Поэтому оставался лишь один путь - через Бессарабию. В то же время между Бухарестом и руководством зондеркоманды «Р» сложились довольно натянутые отношения в вопросах прав и обязанностей этнических немцев на территории Транснистрии. Так, румынское правительство давно настаивало на том, чтобы немецкие колонисты занимались не только сдачей сельхозпродукции гражданской администрации, но и участвовали в снабжении армейских частей королевства, расквартированных в регионе [22, B1. 4].

План эвакуации этнических немцев, разработку которого курировал командир зондеркоманды «Р» бригадефюрер СС Х. Хоффмейер, предполагал несколько вариантов развития событий. Так, в первую очередь следовало начать переселение немецких женщин и детей из 20-километровой полосы вдоль Южного Буга в западную часть Транснистрии. Трудоспособные мужчины должны были остаться выполнять весенние сельскохозяйственные работы. Если бы советские войска продолжили свой натиск, то уже все немецкое население подлежало бы эвакуации в западную часть Транснистрии. В случае приближения Красной армии к Днестру следовало начинать организованный отход на территорию Бессарабии. Местом дислокации самой зондеркоманды «Р» стала бы Вена [23, В1. 8].

В первой половине февраля 1944 г. Х. Хоффмейер провел безуспешные переговоры об эвакуации 135000 этнических немцев из Транснистрии с вице-премьером Румынии М. Антонеску и главой Генерального штаба генералом И. Штефлей. Военно-политическое руководство отказалось от какого-либо содействия в проведении этой акции. Однако штаб зондеркоманды «Р» продолжил разработку эвакуационного плана. Основная ответственность за это была возложена на оберштурмфюрера СС фон Зеефельда. Эвакуацию немецкого населения предполагалось осуществить железнодорожным и водным транспортом. 
В связи с этим зондеркоманда «Р» инициировала переговоры с администрациями Немецких имперских железных дорог и Дунайского пароходства. Разработчики плана исходили из того, что до июня уровень воды в Дунае будет достаточным для перевозки беженцев до Вены. Ключевое значение при проведении будущей операции имел Галац - важный портовый город, в котором следовало вновь, как и в 1940 г., организовать транзитный лагерь. Однако с этим возникли определенные сложности, вызванные отказом румынских властей предоставлять какуюлибо помощь. Округ Вартегау еще до согласования с его администрацией уже рассматривался как регион окончательного расселения немцев из Транснистрии [24].

На территории самой Транснистрии в это время происходила ускоренная подготовка к эвакуации. Сотрудники зондеркоманды «Р» начали оповещать и инструктировать жителей колоний. На учителей и других представителей сельской интеллигенции была возложена задача по сбору статистических сведений, касающихся, например, домовладений, хозяйственного инвентаря, домашнего скота и земельных наделов. Сами жители колоний активно занимались подготовкой гужевого транспорта. Так, за короткий промежуток времени следовало успеть не только подковать всех лошадей, но и соорудить на каждой повозке из брезента или же фанерных листов фургон. Параллельно с этим осуществлялась заготовка провизии. В первую очередь многие колонисты стремились взять с собой консервированное мясо и запасы муки. Во избежание переутомления лошадей при длительном переходе германские власти рекомендовали грузить на подводы максимум 500 килограммов имущества. Основным организационным звеном в эвакуационном потоке являлась колонистская община, которая, в свою очередь, состояла из нескольких групп (по 2224 человека в каждой). В состав групп входили родственники и члены семей. Такой принцип организации должен был укрепить сплоченность и взаимовыручку во время эвакуации [7, S. 43-44].

В начале марта 1944 г. войска 2-го и 3-го Украинского фронтов возобновили наступательные операции на юго-западном направлении. Поэтому 12 марта X. Хоффмейер по со- гласованию с командованием групп армий «Юг» и «А» был вынужден отдать приказ о начале срочной эвакуации всего немецкого населения Транснистрии. На следующий же день штаб зондеркоманды «Р» поставил об этом в известность М. Антонеску. Столь стремительное развитие событий внесло существенные коррективы в упомянутый выше план, подразумевавший поэтапное перемещение немцев к дунайским портам. В частности, возникли серьезные сложности, связанные с техническими аспектами эвакуации. Так, ОКХ издало приказ о переоборудовании всех крупных транспортных кораблей на Дунае в госпитальные судна [25, Bl. 16]. Решение военного командования поставило штаб зондеркоманды «Р» в тупиковое положение, потому что осуществить эвакуацию этнических немцев с помощью железнодорожного транспорта было практически невозможно. Вермахт в ходе переговоров со штабом зондеркоманды «Р» согласился выделить лишь 6 транспортных судов, что, естественно, не способствовало своевременному проведению операции [15, B1. 9284-9285].

Под давлением сложившейся ситуации на фронте правительство Румынии было вынуждено дать согласие на то, чтобы эвакуационный маршрут пролегал по территории Бессарабии. В то же время оно решительно отказалось предоставлять разрешение на размещение беженцев в немецких колониях в румынской части Баната и Трансильвании, поскольку в обоих регионах планировалось расселить полумиллионный контингент румынских беженцев из Бессарабии и Транснистрии. Кроме этого, правительство Румынии запретило использовать речной порт Галац, который имел важное военно-стратегическое значение. Таким образом, разработанный немецкой стороной план по эвакуации нуждался в серьезной корректировке. 17 марта 1944 г. состоялись очередные переговоры между руководством зондеркоманды «Р» и румынским Генеральным штабом, в ходе которых были определены пункты переправы через Днестр: Дубоссары, Тирасполь, Тигина (Бендеры) и, как возможный дополнительный вариант, Овидиополь. Румынская сторона также позволила использовать для отправки беженцев речным транспортом порты Измаил 
и Килия. Однако, как вскоре выяснилось, последний был временно непригоден. В этой ситуации Х. Хоффмейер безуспешно пытался добиться разрешения на использование порта Рени [25, Bl. 15-16].

B середине марта X. Хоффмейер и его шеф обергруппенфюрер СС В. Лоренц обратились напрямую в полевой штаб рейхсфюpepa CC с просьбой помочь как можно скорее убедить ОКВ отказаться от изъятия всех речных судов. Согласно мнению Х. Хоффмейера, вермахт должен был использовать иные пути для транспортировки своих раненых, поскольку наиболее оптимальный эвакуационный маршрут пролегал только по Дунаю. Основной аргумент заключался в том, что румынская сторона решительно отказалась снабжать немецких беженцев продовольствием и кормом для лошадей и остального скота. Впрочем, Х. Хоффмейер попросил полевой штаб рейхсфюрера СС попробовать решить также и эту проблему в кратчайшие сроки с помощью МИДа Германии [15, B1. 9285]. В аппарате СС отреагировали достаточно быстро, поручив бригадефюреру СС Г. Фегелейну, который являлся представителем СС при А. Гитлере, связаться с высшими армейскими инстанциями и МИДом. Предполагалось, что переговоры с Бухарестом должен был инициировать известный в то время дипломат В. Хевель [15, B1. 9281].

Основная ответственность за распространение приказа об эвакуации была возложена на филиал ФоМи в Одессе [9, S. 182]. В свою очередь, непосредственное оповещение немецкого населения обеспечивали сотрудники районных команд, которые пытались предотвратить нарастание панических настроений и в то же время могли предупреждать о негативных последствиях возвращения советской власти [20, S. 168].

В соответствии с распоряжением штаба зондеркоманды «Р» жителям березанских и глюкстальских колоний следовало перейти на другой берег Днестра в Тирасполе и Дубоссарах. Овидиополь же должен был стать пунктом переправы для беженцев из кучурганских и грослибентальских колоний $[9$, S. 182].

К середине марта зондеркоманда «Р» еще не успела проинструктировать все немец- кое население Транснистрии о предстоящей эвакуации, поэтому жители некоторых колоний начали к ней активно готовиться лишь после объявления официального приказа [20, S. 168]. Первая фаза эвакуации должна была производиться преимущественно гужевым транспортом. Однако не все немецкие семьи имели возможность подготовить крытую повозку для длительного перехода. Например, с такими сложностями иногда сталкивались люди, относившиеся по роду своей профессиональной деятельности к сельской интеллигенции $[2$, с. $136 ; 26]$. В более серьезной ситуации оказались многие жители колонии Ландау. Они попали в число тех, у кого за несколько дней до объявления об эвакуации представители вермахта реквизировали лошадей и повозки для своих транспортных нужд, поэтому лишь некоторая часть колонистов смогла отправиться в путь на подводах. Для других германские власти смогли пригнать с соседней станции три эшелона, в которые в первую очередь погрузили людей пожилого возраста, больных и женщин с маленькими детьми. Тем не менее этого оказалось недостаточно, и оставшихся беженцев пришлось через некоторое время вывозить самолетами в направлении Одессы [10, S. 49-50]. Согласно воспоминаниям колонистов, в тот же день еще некоторое количество немецких семей покинули Ландау на грузовиках вместе с сотрудниками штаба зондеркоманды «Р» [27, S. 14]. По схожему сценарию происходила и эвакуация жителей колонии Хофнунгсталь. Лица пожилого возраста и женщины с детьми были доставлены на станцию Веселый Кут и затем погружены в поезд. Медико-санитарным обслуживанием данного контингента занимался персонал из находившегося поблизости санитарного лагеря Немецкого Красного Креста [26]. В общей сложности до конца марта в Лицманштадт (Лодзь) тремя эшелонами было доставлено 4097 человек. Различные способы транспортировки применялись и при эвакуации немцев, которые проживали в городах. Например, для доставки беженцев из Одессы в Аккерман (БелгородДнестровский) использовались грузовики и самолеты [25, Bl. 16].

Продвижение беженцев, эвакуировавшихся на подводах, нередко осложнялось ве- 
сенней распутицей. Так, один из участников перехода написал в своем дневнике, что вода и грязь превратились в труднопроходимую жижу, в которой глубоко увязали колеса телег. Передвижение по холмистой местности в таких условиях было особенно сложным. Для более или менее успешного перехода через холмы следовало иметь в упряжке 4-6 лошадей, поэтому довольно часто беженцы были вынуждены разгружать со своих повозок часть провизии и имущества $[18, \mathrm{p} .11]$. Также стоит отметить, что продолжительные дожди в первой половине марта помешали жителям некоторых березанских колоний вовремя начать эвакуацию, как того требовал приказ [27, S. 15]. Кроме погодных условий на продвижение беженцев оказывали влияние и другие факторы. Например, в начале двадцатых чисел марта мост через Днестр в Тирасполе был запружен отступавшими немецкими частями, поэтому двигавшиеся к этой переправе отдельные группы беженцев получили приказ свернуть к Овидиополю. Однако два дня спустя они были вынуждены вновь изменить свой маршрут в направлении Тирасполя. В конечном итоге им удалось переправиться на другой берег Днестра в Дубосса$\operatorname{pax}[27$, S. 16]. Переход колонистов через реку в Тирасполе вскоре был облегчен благодаря тому, что немецкие военные возвели понтонный мост [19, S. 170].

Сильное стрессогенное воздействие на многих эвакуировавшихся немцев оказывал постоянный страх перед приближающейся линией фронта. Некоторые их обозы были все же настигнуты частями Красной армии. Определенная угроза исходила и от партизанских отрядов, проводивших свои рейды в немецко-румынском тылу. Так, в конце марта советские партизаны внезапно появились возле села Маяки, где в тот момент жители колонии Зельц уже заканчивали свою переправу через Днестр. Бойцы отряда тут же открыли огонь по отплывавшему парому и успели захватить оставшуюся многочисленную группу немецких беженцев [27, S. 24]. После этого, согласно некоторым данным, партизаны в качестве меры устрашения отобрали и расстреляли на берегу реки девятерых мужчин [3, c. 193; 8]. Жители Зельца, не успевшие пересечь Днестр, в итоге были вынуждены вер- нуться в свою колонию [27, S. 24]. Кроме партизан серьезную опасность для беженцев представляла и советская авиация, под бомбовые удары которой они время от времени попадали.

Первая фаза операции по эвакуации немцев из Транснистрии в общей сложности длилась до 9 апреля 1944 года. Наиболее продолжительной из-за плохих погодных условий оказалась переправа беженцев через Днестровский лиман. Временное расквартирование эвакуированного контингента происходило преимущественно в южных районах Бессарабии. В первой половине апреля около 22000 человек (преимущественно немощные старики, больные и женщины с детьми) были отправлены поездами в Лицманштадт. Некоторые группы перевозились в открытых вагонах [6].

26 марта 1944 г. Х. Хоффмейер, чей штаб к тому времени был перенесен в Галац, провел в Бухаресте телефонный разговор с заместителем главы Генштаба армии Румынии генералом С. Мардари, в ходе которого обсуждались некоторые технические детали дальнейшей эвакуации немцев из Транснистрии. В первую очередь С. Мардари упомянул о результатах недавней встречи маршала И. Антонеску с А. Гитлером. Как выяснилось, кондукэтор был намерен своим распоряжением полностью прекратить любые перемещения гражданского населения через территорию Румынии. Х. Хоффмейер решительно заявил, что данное распоряжение не должно распространяться на немецких беженцев из Транснистрии. В свою очередь генерал С. Мардари сообщил о согласии румынского Генштаба на переход беженцев через территорию Бессарабии. Далее он отметил, что за отведение зон для временного размещения контингента и портов / пристаней на Дунае будет отвечать командование группой армий «А». Кроме этого, в случае дальнейшего наступления войск Красной армии запрещалась дальнейшая переправа беженцев через Прут. Сам Х. Хоффмейер должен был позаботиться о том, чтобы эвакуация немцев по территории Бессарабии прошла как можно быстрее и исключительно по Дунаю. Румынская сторона отказалась принимать какое-либо участие в транспортном обеспечении этой акции. После разговора с представителем 
Генштаба Х. Хоффмейер телеграфировал Г. Гиммлеру о своем намерении встретиться в ближайшее время с вице-премьером М. Антонеску для подтверждения полученной информации и выяснения других возможных деталей [13, B1. 9276-9278].

Переговоры руководства СС с вермахтом о предоставлении речных кораблей для эвакуации немецкого населения Транснистрии продолжались до конца марта 1944 года. В оперативном штабе вооруженных сил все же выразили готовность пойти на определенный компромисс. Так, 24 марта генерал В. Варлимонт заявил о согласии ОКВ предоставить как железнодорожный, так и речной транспорт (в последнем случае речь шла о судах из состава речной флотилии вермахта). При этом он подчеркнул, что практически все гражданские суда на Дунае будут использованы для транспортировки раненых. В качестве исключения ОКВ могло также выделить через некоторое время около 20 венгерских пассажирских пароходов [15, B1. 9280]. Однако уполномоченный рейха в Будапеште Э. Веезенмайер, который оказывал содействие в разрешении сложившейся ситуации, вскоре сообщил более точные данные не только о количестве, но и о состоянии этих судов. Как выяснилось, в распоряжении военных в действительности имелось 16 пароходов, из которых 5 планировалось использовать как санитарный транспорт. Среди оставшихся 11 судов лишь некоторые оказались пригодными для осуществления эвакуации немцев Транснистрии. Э. Веезенмайер пообещал попытаться договориться о предоставлении этих пароходов в распоряжение ФоМи. Однако он подчеркнул, что изъятие речных судов может негативно отразиться на снабжении самого Будапешта, который ранее серьезно пострадал от налетов советской авиации. Глава ФоМи обергруппенфюрер СС В. Лоренц со своей стороны решил обратиться к ОКВ с просьбой выделить в ближайшее время 5 вышеупомянутых пароходов, поскольку от этого зависел исход всей эвакуации. Активное дипломатическое содействие продолжал оказывать и МИД Германии, поручивший своему послу в Бухаресте М. фон Киллингеру инициировать очередные переговоры о временном размещении беженцев в немецких колониях на тер- ритории румынской части Баната и Трансильвании [15, Bl. 9290-9292].

31 марта 1944 г. Г. Гиммлер сообщил главе ФоМи В. Лоренцу о том, что все эвакуированные из Транснистрии немцы будут окончательно расселены в округе Вартегау. Как выяснилось, данный план рейхсфюрер СС вынашивал уже давно и даже успел заранее уведомить о нем гауляйтера А. Грейзера, одобрившего эту идею. В тот же день Г. Гиммлер отправил в Позен (Познань) еще одну телеграмму, в которой выразил главе округа признательность за его согласие принять и разместить около 130000 немцев из Транснистрии. Он также пообещал, что данный контингент останется в Вартегау и после завершения войны. В конце телеграммы Г. Гиммлер как рейхскомиссар по укреплению немецкой народности поручил А. Грейзеру организовать расселение беженцев на территории округа [11, B1. 9268-9269].

К началу апреля координация между СС и командными инстанциями вермахта в вопросе организации эвакуации этнических немцев вышла на новый уровень. Так, 13 апреля 1944 г. был выпущен циркуляр генерал-квартирмейстера Генерального штаба ОКХ, который уже более конкретно определял роль и полномочия ФоМи и армейских структур. Основное руководство операцией по-прежнему осуществлял штаб зондеркоманды «Р». Также, в соответствии с распоряжением ОКВ от 2 апреля 1944 г., на немецкого генерала при Главном командовании румынских королевских вооруженных сил Э. Ханзена возлагалась ответственность за отправку беженцев в случае обострения ситуации на фронте. В частности, он был уполномочен ускорить дальнейшую эвакуацию большинства этнических немцев из северной части Румынии на подводах. Для отправки других групп немецких беженцев следовало подготовить железнодорожный и речной транспорт. Генерал должен был оказывать посильную помощь бригадефюреру СС Х. Хоффмейеру, имевшему в своем распоряжении весьма ограниченные ресурсные возможности, в снабжении переселенческого контингента продовольствием. В данном циркуляре ОКВ также допускало использование дунайских пароходов, переоборудованных в плавучие госпитали, но в зависимости от бое- 
вой обстановки [16, Bl. 9258-9259]. Кроме этого, на ограниченной территории предполагалось задействовать дополнительный армейский автотранспорт. В соответствии с разработанным планом, колонны беженцев на подводах должны были начать движение по шоссейным дорогам вдоль обоих берегов Дуная. Примечательно, что к моменту выхода циркуляра ОКВ Генштаб Румынии еще не предоставил германской стороне свое официальное разрешение на транзит. Решение данного вопроса было поручено генералу Э. Ханзену. Переговоры о разрешении перехода по территории Болгарии планировалось вести по линии МИДа Германии (через его дипломатическую миссию в Софии) и ОКВ (через немецкого генерала при Главном командовании Королевской армией). Дальнейший путь беженцев должен был пролегать через сербскую часть Баната, где они могли на некоторое время остановиться на отдых. Вопрос об их размещении следовало предварительно согласовывать с командованием группой армий «Ф». Отправку немецкого контингента с территории сербского Баната планировалось производить уже железнодорожными составами. Организационную ответственность за эту фазу операции несло руководство ФоМи [16, B1. 9258-9259].

Однако вскоре стало очевидно, что вышеописанный план нуждается в серьезном пересмотре. Эвакуировать такое большое количество этнических немцев через Южную Румынию, особенно в кратчайшие сроки, было просто невозможно как из-за наплыва румынских беженцев из северной части страны, так и из-за весьма ограниченных транспортных возможностей.

В связи с этим при проведении следующей фазы эвакуации власти Германии планировали сформировать два больших потока немецких беженцев - северный и южный. Первый, который состоял преимущественно из жителей березанских и глюкстальских колоний, должен был продолжать свой отход через территорию Венгрии. Южный поток объединял уроженцев кучурганских и грослибентальских колоний, а также Одессы. Эвакуационный маршрут этого контингента пролегал по территории Болгарии, Сербии, Венгрии, протектората Богемии и Моравии и Генерал-губернаторства. Каждым из двух потоков руко- водил представитель ФоМи в звании гауптштурмфюрера СС, который, в частности, отвечал за организацию временного размещения и питания беженцев [9, S. 182; 27, S. 9-10].

Первым 16 апреля 1944 г. по распоряжению генерал-квартирмейстера ОКХ через Бырлад и венгерскую Северную Трансильванию начал движение из Бессарабии северный поток беженцев [14, B1. 9243-9244]. Он состоял из 70125 человек, 38444 лошадей, 12729 повозок и 6458 голов крупного рогатого скота [12, S. 223]. Переход через Прут происходил по мосту возле деревни Фэлчу. Из-за постоянных налетов советской авиации и движения немецких частей маршрут обоза нередко корректировался [27, S. 9].

ОКВ поначалу сомневалось в том, что Северная Трансильвания, имевшая весьма ограниченные ресурсные возможности, способна принять даже на короткий промежуток времени такой многочисленный контингент беженцев [14, B1. 9246]. Исходя из этого, штаб зондеркоманды «Р» и генерал Э. Ханзен должны были находиться в тесной координации с командующим германскими войсками в Восточной Венгрии. Последний, в частности, имел право принять в зоне своей ответственности ограниченное количество этнических немцев. Согласно предписанию ОКВ, переход беженцев по венгерской территории должен был продолжаться до линии Клаузенбург (КлужНапока) - Деж - Бетлен - Быстрица - Боргопрунд - Пояна-Стампей. Кроме того, им запрещалось совершать остановки длительностью более 24 часов. Практически всю ответственность за управление перемещением, сопровождение, организацию питания и медицинского обслуживания немецких беженцев нес штаб зондеркоманды «Р». Дальнейшую отправку контингента эшелонами за пределы Венгрии следовало заранее согласовать с транспортными службами вермахта [14, B1. 9241-9242].

Движение обоза по территории Северной Трансильвании проходило в сопровождении венгерских солдат, которые обеспечивали не только защиту, но и занимались поставкой продовольствия [27, S. 9, 17]. Наиболее сложная фаза маршрута была связана с переходом через Восточные Карпаты. К концу апреля первые группы северного потока смогли вый- 
ти к вышеупомянутой рубежной линии. Перед погрузкой в эшелоны в городе Деж беженцы получали продуктовый паек на десять дней. Их лошади подлежали сдаче специальной комиссии вермахта, которая взамен выдавала квитанции [27, S. 17].

Отправка поездов с беженцами из Венгрии в рейх продолжалась почти целый месяц с 4 по 29 мая [6]. Маршрут многих эшелонов пролегал через Будапешт. После прибытия в Вартегау весь контингент проходил санитарную обработку (душ и дезинсекцию). Первоначально германские власти предполагали направлять этнических немцев из Транснистрии в лагерь Пабьянице. Однако, как вскоре выяснилось, его пропускной способности оказалось явно недостаточно для обслуживания такого большого количества людей. В связи с этим было принято решение выделить еще два пересыльных лагеря - в Лицманштадте и Гёрнау [5].

Наиболее сложной, особенно в организационном плане, оказалась эвакуация этнических немцев по южному маршруту. Так, 14 апреля 1944 г. состоялась встреча генерала Э. Ханзена с маршалом И. Антонеску, в ходе которой обсуждались технические аспекты отправки около 60000 беженцев к болгарской границе. Наиболее решительное возражение со стороны премьер-министра вызвала идея эвакуировать часть этого контингента пароходами, поскольку некоторые участки дунайского фарватера были заминированы. К слову, один из шести вышеупомянутых пароходов к тому времени уже вышел из строя, подорвавшись на мине. Отправка немцев железнодорожным транспортом также была временно невозможна. Таким образом, эвакуация на подводах вдоль берегов Дуная оставалась единственным возможным вариантом [14, Bl. 9249-9250]. В тот же день последовали известия от представителя ОКВ генерала В. Варлимонта, который сообщил, что пропускные возможности шоссейных дорог Южной Румынии весьма ограниченны из-за наплыва беженцев из северной части страны [14, B1. 9254]. Особенно серьезные опасения данная ситуация вызывала со стороны командования группы армий «Южная Украина», вынуждая его принимать некоторые превентивные меры. Так, 14 апреля начальник армейс- кого штаба генерал В. Венк поставил руководство зондеркоманды «Р» в известность о разрешении на перемещение вдоль Дуная лишь 40000 этнических немцев из Транснистрии, в противном случае более многочисленный контингент мог бы парализовать дорожное движение. Принимая во внимание требование армейского командования, Х. Хоффмейер подписал приказ об эвакуации 40000 человек. Остальная же часть контингента должна была ожидать своей очереди. Временное размещение беженцев планировалось организовать в районе Панчево (территория сербского Баната) [14, B1. 9256-9257].

Однако вскоре со своей инициативой выступило ОКВ, решившее направить южный поток беженцев за пределы Румынии по кратчайшему маршруту. Основной замысел заключался в следующем: движение людей должно было происходить по правому берегу Дуная, то есть по болгарской территории. Переход беженцев в Болгарию следовало осуществить через Добруджу, северная часть которой относилась к зоне боевых действий. Провести переговоры по данному вопросу с маршалом И. Антонеску ОКВ поручило генералу Э. Ханзену и посольству Германии в Бухаресте. Представители германской стороны должны были также попытаться уговорить кондукэтора разрешить использовать для ускорения эвакуации немецких беженцев из Румынии дополнительный транспортный маршрут - фарватер Дуная от Галаца до Силистрии. Еще один аргумент со стороны ОКВ заключался в том, что подобный способ транспортировки помог бы избежать «неблагоприятного (деморализующего. - B. М.) воздействия на румынское население» $[14, \mathrm{Bl}$. 92469247]. Вопрос о краткосрочном использовании дунайского фарватера требовалось также согласовать с командованием группы армий «Южная Украина» и соответствующими транспортными инстанциями. Кроме этого, ОКВ предписало использовать для эвакуации этнических немцев с территории Румынии любой доступный транспорт - как речной, так и железнодорожный. Генерал Э. Ханзен получил от ОКВ довольно широкие административные полномочия, например право отдавать распоряжения региональным представителям германского командования (немецкому гене- 
ралу при Главном командовании Королевской армией Болгарии, главнокомандующему немецкими войсками Юго-Востока и атташе вермахта в Венгрии) относительно проведения операции на той или иной территории. Однако при этом он должен был действовать в тесной координации с ФоМи [14, B1. 9247-9248].

Движение южного потока, в состав которого входило 40000 человек, 8000 повозок, 19000 лошадей и 5000 голов крупного рогатого скота, началось 23 апреля 1944 г. [6]. Переход через Прут состоялся по понтонному мосту возле города Рени. Дальнейший маршрут обоза по румынской территории пролегал через Галац, Браилу, Исакчу, Тулчу и Чернаводэ. В начале мая колонны беженцев достигли румынско-болгарской границы. Первым транзитным пунктом на территории Болгарии, как и планировалось, стала Силистpa $[27$, S. 10].

Переход этнических немцев через территорию Болгарии оказался, пожалуй, наиболее благоприятной фазой в эвакуации. Так, в мемуарных свидетельствах беженцев содержится немало упоминаний о доброжелательном отношении к ним со стороны местного населения: «в Силистре, приграничном городе, нас приняли очень хорошо. Люди подходили к нам с хлебом, выпечкой, фруктами и всем остальным, что у них было» [26]; «болгары были хорошо настроены и сочувствовали нам. Жизнь там выглядела довольно мирной. Мы завидовали болгарам» [27, S. 21]; «до сих пор мы не ощущали такой помощи и открытости» [18, p. 19-20].

27 апреля командующий полицией безопасности и СД в Сербии штурмбанфюрер СС Э. Вейман обсудил с двумя представителями ФоМи ряд важных вопросов, касающихся эвакуационного маршрута этнических немцев. В частности, он предупредил, что после перехода через болгарско-сербскую границу в районе Видина дальнейший путь беженцев будет пролегать по территории, которую в значительной мере контролируют отряды партизанской армии И. Тито. Многочисленные обозы, состоявшие из 8000 повозок, 20000 лошадей и 10000 голов крупного рогатого скота, без усиленного вооруженного сопровождения обязательно подверглись бы нападению. В связи с этим Э. Вейман внес предложение изменить маршрут беженцев: их колонны следовало перенаправить из района Видина на румынскую территорию, где они продолжили бы дальнейший путь по левому берегу Дуная до румынско-сербской границы. О деталях разговора в тот же день сообщили генералу Э. Ханзену, который принял во внимание серьезность партизанской угрозы. Он пообещал как можно скорее согласовать изменение эвакуационного маршрута с правительством Румынии. При этом, учитывая непростой характер румынско-германских отношений, Э. Ханзен попросил ОКВ поддержать его позицию в очередных переговорах [21, B1. 906]. В итоге спустя некоторое время разрешение на переход беженцев по левому берегу Дуная было получено.

В конце мая 1944 г. первые обозы немцев из Транснистрии достигли Видина. Переправа на противоположный берег, где находился румынский город Калафат, осуществлялась с помощью большого железнодорожного парома, который за один раз мог вместить около 100 повозок, включая лошадей $[19$, S. 173174], благодаря чему удалось сократить сроки форсирования беженцев через Дунай.

Переход по территории Румынии прошел почти без серьезных эксцессов, за исключением лишь одного случая, когда обоз беженцев попал под удар англо-американской авиации. Впрочем, этот налет не привел к значительным человеческим жертвам [6].

Первые группы немецких беженцев из Транснистрии вступили на территорию сербского Баната 9 июня 1944 года. По решению германских властей данный контингент должен был сразу же направляться к деревне Ясенево (район Бела-Црква), находившейся в 11 км от сербско-румынской границы. После кратковременного отдыха и медицинского осмотра все беженцы подлежали отправке (примерно по 1400 человек в день) железнодорожным транспортом в Германию. Первый эшелон отбыл из Ясенево уже 10 июня [21, B1. 909].

Организацией размещения и опекой беженцев из Транснистрии занимались представитель ФоМи и главный фюрер немецкого населения Баната Й. Янко. Медицинское обслуживание осуществлялось персоналом Немецкого Красного Креста и старшим санитарным 
офицером при главнокомандующем немецкими войсками Юго-Востока. К этой работе, по распоряжению Й. Янко, также вскоре подключился «Женский союз» (Frauenschaft). Интендантская служба несла ответственность за обеспечение беженцев питанием на протяжении трех дней [21, B1. 904-905].

Перед отправкой из Ясенево все этнические немцы в обязательном порядке проходили санобработку (мытье и дезинсекцию) [21, Bl. 909]. Большая часть лошадей и крупного рогатого скота подлежала сдаче. Взамен выдавались квитанции, по которым, как предполагалось, немцы могли бы получить компенсацию в Вартегау [27, S. 22]. Значительный интерес в реквизиции лошадей проявлял вермахт. Также было принято решение о передаче около 3000 лошадей Сербскому и Черногорскому добровольческим корпусам [21, Bl. 910]. Помимо реквизиции, представители вермахта занимались вербовкой мужчин в Вооруженные силы Германии [7, S. 47].

Отправка эшелонов из Ясенево продолжалась до 2 июля 1944 г. [6]. Дальнейшая транспортировка беженцев в Лицманштадт проходила по территории Венгрии, протектората Богемии и Моравии и Генерал-губернаторства. 27 июля главный фюрер СС и полиции Вартегау Х. Райнефарт доложил Г. Гиммлеру об окончании последней акции по переселению этнических немцев из СССР в рейх $[12$, S. 224]. Вскоре после этого печатный орган НСДАП «Ostdeutscher Beobachter» патетически заявил о том, что отныне переселенцы из Транснистрии будут трудиться и сражаться в единстве с немецким народом, способствуя тем самым дальнейшему превращению территории округа в «цитадель германизма» [6].

После завершения эвакуации этнических немцев из Транснистрии фактически прекратила свое существование и зондеркоманда «Р». Судьба некоторых ее сотрудников имела трагический финал. Как известно, произошедший 23 августа 1944 г. в Бухаресте государственный переворот привел к радикальному изменению внешнеполитического курса страны. Введенные вскоре после этого в столицу Румынии части германской армии с целью подавить начавшееся там восстание были вынуждены капитулировать 31 августа.
В румынский плен также попало около 20 сотрудников ФоМи, включая самого бригадефюpepa CC X. Хоффмейера. На протяжении двух - трех недель эта группа офицеров СС временно содержалась в бараках города Крайова и фактически находилась в положении интернированных. Согласно некоторым данным, Х. Хоффмейер, стремясь избежать попадания в советский плен, пытался путем подкупа договориться с румынскими офицерами о своем освобождении. Однако данный план, предполагавший переход линии фронта в румынской военной форме, так и не был реализован. В итоге Х. Хоффмейер и его заместитель оберштурмфюрер СС Мюллер покончили с собой. Остальных офицеров зондеркоманды «Р» вскоре этапировали в советский лагерь для военнопленных. Некоторые из них впоследствии были расстреляны по обвинению в преступлениях, совершенных на оккупированных территориях [29, B1. 250-251] ${ }^{2}$.

Результаты. Начавшаяся в марте 1944 г. на территории Транснистрии эвакуация подвела черту в почти полуторавековой истории многочисленных немецких колоний, которые вносили заметное своеобразие в этнокультурный ландшафт Юга Украины. Можно с уверенностью сказать, что подавляющее большинство немцев решили оставить свои дома не под административным давлением со стороны оккупационных властей, а добровольно, руководствуясь исключительно инстинктом собственного выживания. Данный мотив достаточно четко прослеживается во многих мемуарных источниках. Впрочем, гитлеровская Германия, несмотря на весь пропагандистский пафос о спасении своих соплеменников, не смогла стать для переселенцев второй родиной. В переполненных лагерях на территории Вартегау немцев из Транснистрии ожидала комплексная проверка, в ходе которой весь контингент подвергался селекции, в том числе и по расово-антропологическому признаку. Лица, которые успешно прошли фильтрацию, как правило, получали гражданство рейха, но не равные права: одна часть переселенцев была необходима для дальнейшего укрепления германского влияния на аннексированных польских землях, в то время как другая подлежала трудовому использованию в экономике «старого рейха» ${ }^{3}$. Кроме того, на заверша- 
ющем этапе войны тысячи мужчин добровольно или же в результате мобилизации оказались в рядах Вооруженных сил Германии.

\section{ПРИМЕЧАНИЯ}

\begin{abstract}
1 Зондеркоманда «Россия» (Sonderkommando Russland; в документах часто фигурирует как Sonderkommando «R») - структурное подразделение ФоМи, являвшееся основным куратором в вопросах регистрации и опеки этнических немцев на оккупированных советских территориях.

2 Документ любезно предоставлен доктором А. Ангриком (Гамбург).

${ }^{3}$ «Старый рейх» (нем. Altreich) - условное название всех территорий, входивших в состав Германии до 1938 года.
\end{abstract}

\section{СПИСОК ЛИТЕРАТУРЫ}

1. Полян, П. М. Жертвы двух диктатур : Жизнь, труд, унижения и смерть советских военнопленных и остарбайтеров на чужбине и на родине / П. М. Полян. - М. : РОССПЭН, 2002. -896 c.

2. Романько, О. В. Военный коллаборационизм и нацистская печатная пропаганда на территории Крыма в 1941-1944 гг. (по материалам газеты «Голос Крыма») / О. В. Романько // Вестник Волгоградского государственного университета. Серия 4 , История. Регионоведение. Международные отношения. - 2019. - Т. 24, № 1. - С. 130-139. - DOI: https://doi.org/10.15688/jvolsu4.2019.1.11.

3. Романько, О. В. Как короли стали пешками (Рец. на кн.: Cloutier, P. Three Kings: Axis Royal Armies on the Russian Front 1941 [Text] / P. Cloutier. Charleston, SC : Createspace Independing Publishing Platform, 2015. - 160 р.) / О. В. Романько // Вестник Волгоградского государственного университета. Серия 4, История. Регионоведение. Международные отношения. - 2018. - Т. 23, № 1. - С. 190-194.DOI: https://doi.org/10.15688/jvolsu4.2018.1.18.

4. Чернявський, В.В.Примусова праця цивільного населення Миколаївської області в Третьому рейху та Румунії 1941-1943 рр.: вербування, експлуатація, особливості повоєнної репатріації / В. В. Чернявський // Книга Памяти Украины : Николаевская область. - Николаев : Илион, 2014. - Т. 15. - С. 45-133.

5. Austen, H. Auch die Deutschen aus Transnistrien kehren heim/H. Austen // Litzmannstädter Zeitung. - 1944. - 15. Juli (№ 197).

6. Bamm, P. Der große Kriegstreck 1944 / P. Bamm // Ostdeutscher Beobachter. - 1944. - 23. Juli (№ 201).

7. Bauer, J. Umsiedlung der Deutschen aus der Gemeinde Aleksanderhilf, Kreis Odessa nach dem
Warthegau 1944 / J. Bauer // Heimatbuch der Deutschen aus Russland. - Stuttgart : LMDR e. V., 1966. - S. 43-48.

8. Bosch, A. Das Drama der Selzer am Dnjester / A. Bosch. - Electronic text data. - Mode of access: http://www.russianroots.ca/images/rrstory6.pdf(date of access: 11.06.2019). - Title from screen.

9. Bosch, A. Entstehung, Entwicklung und Auflösung der deutschen Kolonien am Schwarzen Meer am Beispiel von Kandel von 1808 bis 1944 / A. Bosch, J. Lingor. - Stuttgart : Landsmannschhaft der Dt. aus Russland, 1990. - 573 S.

10. Braun, G. Auszug eines Briefes, geschrieben im April 1944 aus Turnu-Severin/Rumänien, der letzten Verpflegungsstation des Südtrecks aus Transnistrien / G. Braun // Heimatbuch der Deutschen aus Russland. Stuttgart : LMDR e. V., 1966. - S. 49-51.

11. Fernschreiben, Greiser, Himmler, Greifelt, Lorenz, 30. März-02. April 1944: Stand der Transnistrien-Umsiedlung, Zusicherung RFSS für Greiser, dass Russlanddeutsche endgültig im Wartheland verbleiben; Unterstellung der Ansiedlungsstäbe unter die Landräte // Archiv des Instituts für Zeitgeschichte-München (IfZ-Archiv). MA 303/1. - Bl. 9264-9274.

12. Fleischhauer, I. Das Dritte Reich und die Deutschen in der Sowjetunion / I. Fleischhauer. Stuttgart : Deutsche Verlags - Anstalt, 1983. $257 \mathrm{~S}$.

13. Geheimes Fernschreiben Hoffmeyer, RFSS, 26. März 1944; Besprechung Hoffmeyer mit General Madare, stellvertretender Chef des rumänischen Generalstab betr. Rückführung der Deutschen aus Transnistrien // IfZArchiv. - MA303/1. - Bl. 9275-9279.

14. Geheimes Fernschreiben Lorenz, Hildebrandt, Warlimont, Hoffmeyer an RFSS, 19. Januar-22. Mai 1944: Durchmarsch des Nord- und Südtrecks aus Transnistrien durch Bulgarien, Rumänien und Ungarn; anfängliche Einwände Marschall Antonescu gegen Durchmarsch durch Dobrudscha // IfZ-Archiv. MA 303/1.-Bl. 9232-9257.

15. Geheime Fernschreiben Warlimont, Lorenz, Hoffmeyer u.a., 12. März-12. April 1944: Abmarschbefehl für deutsche Volksgruppe Transnistrien infolge militärischer Lage am 12. März 1944; Auffangräume, Grenzübergänge, Transportlage, Donauschiffe und Eisenbahnzüge der Wehrmacht; Versorgungsschwierigkeiten // IfZ-Archiv. MA303/1.-Bl.9280-9292.

16. Geheimes Rundschreiben Generalstab des Heeres, 13. April 1944: Kompetenzen, Transport- und Verpflegungsfragen bei Abschub Volksdeutscher aus Nordrumänien//IfZ-Archiv. -MA303/1.-Bl. 9258-9260.

17. Hoffmann, R. Das Ende der volksdeutschen Siedlungen in "Trarisnistrien" im Jahre 1944/ R. Hoffmann // Aus der Arbeit des Bundesarhivs. - Boppard a. Rh. : [s. n.], 1977.-S. 447-453. 
18. Hornbacher, W. Removal from the Homeland: A Surviving Eyewitness Documentary Report on the Evacuation of Ethnic Germans from the Black Sea Region of Ukraine to Germany in Early 1944 (Part I) / W. Hornbacher ; transl. and ed. by Eric J. Schmaltz // Heritage Review. - 2008. - Vol. 38, № 1 (March). - P. 8-38.

19. Kuck, G. Der Große Treck 1944 / G. Kuck // Heimatbuch der Deutschen aus Russland. - Stuttgart : LMDR e. V., 2003. - S. 169-174.

20. Malsam, M. Unser Weg vom Schwarzen Meer über den Warthegau an die Petschora / M. Malsam // Heimatbuch der Deutschen aus Russland. - Stuttgart : LMDR e. V., 1992-1994. - S. 165-175.

21. Militärbefehlshaber Südost / Oberquartier: KTB vom 01. Januar 1944-30. Juni 1944; Eintragungen über Ausrüstung des Serbischen Freiwilligenkorps, der serbischen Staatswache, der sogenannten "VertragsCetniks" und die deutschen Truppen mit Waffen und Munition, Versorgung deutscher Flüchtlingstransporte aus Transnistrien// IfZ-Archiv. -MA690. - B1. 888-910.

22. Monatsbericht, Volksdeutsche, Mittelstelle, Amt VII, Dezember 1943 // Bundesarchiv Berlin (BAB). - R 59/68. - Bl. 2-4.

23. Monatsbericht, Volksdeutsche Mittelstelle, Amt VII, Januar 1944 // BAB. - R 59/68. - Bl. 5-8.

24. Monatsbericht, Volksdeutsche Mittelstelle, Amt VII, Februar 1944 // BAB. - R 59/68. - Bl. 11-12.

25. Monatsbericht, Volksdeutsche Mittelstelle, Amt VII, März 1944 // BAB. - R 59/68. - Bl. 13-17.

26. Peterreins, G. Unsere Rückkehr nach Deutschland/G. Peterreins. - Electronic text data. - Mode of access: http://www.blackseagr.org/pdfs/gertrudes_ diary-german.pdf(date of access: 08.06.2019). - Title from screen.

27. Schwindt, W. Der siebte Treck / W. Schwindt, V. Schäfer, E. Stephan // Heimatbuch der Deutschen aus Russland. - Stuttgart: LMDR e. V., 2004. - S. 6-28.

28. Völkl, E. Transnistrien und Odessa (19411944) / E. Völkl. - Regensburg : [s. n.], 1996. - 124 S.

29. Zeugenvernehmung von Walter Paul Vahldieck, Hamburg, den 27. Mai 1963 // Bundesarchiv-Außenstelle, Ludwigsburg. -B 162/2302.-Bl. 229-251.

\section{REFERENCES}

1. Polyan P.M. Zhertvy dvukh diktatur: Zhizn, trud, unizheniya i smert sovetskikh voennoplennykh $i$ ostarbayterov na chuzhbine i na rodine [Victims of Two Dictatorships: Life, Work, Humiliation and Death of Soviet Prisoners of War and Ostarbayters in a Foreign Country and at Home]. Moscow, ROSSPEN Publ., 2002. 896 p.

2. Romanko O.V. Voennyy kollaboratsionizm i natsistskaya pechatnaya propaganda na territorii Kryma v 1941-1944 gg. (po materialam gazety «Golos
Kryma») [Military Collaboration and Nazi Printed Propaganda on the Territory of Crimea in 1941-1944 (Based on the Materials of Newspaper Golos Kryma)]. Vestnik Volgogradskogo gosudarstvennogo universiteta. Seriya 4, Istoriya. Regionovedenie. Mezhdunarodnye otnosheniya [Science Journal of Volgograd State University. History. Area Studies. International Relations], 2019, vol. 24, no. 1, pp. 130139. DOI: https://doi.org/10.15688/jvolsu4.2019.1.11.

3. Romanko O.V. Kak koroli stali peshkami (Rets. na kn.: Cloutier, P. Three Kings: Axis Royal Armies on the Russian Front 1941 [Text] / P. Cloutier. - Charleston, SC: Createspace Independing Publishing Platform, 2015. - 160 p.) [How Kings Became Pawns (Book Review: Cloutier, P. Three Kings: Axis Royal Armies on the Russian Front 1941 [Text] / P. Cloutier. Charleston, SC: Createspace Independing Publishing Platform, 2015. - 160 p.)]. Vestnik Volgogradskogo gosudarstvennogo universiteta. Seriya 4, Istoriya. Regionovedenie. Mezhdunarodnye otnosheniya [Science Journal of Volgograd State University. History. Area Studies. International Relations], 2018, vol.23, no. 1, pp. 190-194. DOI: https://doi.org/10.15688/ jvolsu4.2018.1.18.

4. Chernyavskiy V.V. Primusova pratsya tsivilnogo naselennya Mikolaivskoi oblasti v Tretomu reykhu ta Rumunii 1941-1943 rr.: verbuvannya, ekspluatatsiya, osoblivosti povoiennoi repatriatsii [Forced Labor of Civilians of Mykolaiv Region in the Third Reich and Romania 1941-1943: Recruitment, Exploitation, Features of Post-War Repatriation]. Kniga Pamyati Ukrainy: Nikolaevskaya oblast [Book of Memory of Ukraine: Mykolaiv Region]. Nikolaev, Ilion, 2014, vol. 15, pp. 45-133.

5. Austen H. Auch die Deutschen aus Transnistrien kehren heim. Litzmannstädter Zeitung, 15. Juli 1944, no. 197.

6. Bamm P. Der große Kriegstreck 1944. Ostdeutscher Beobachter, 23. Juli 1944, no. 201.

7. Bauer J. Umsiedlung der Deutschen aus der Gemeinde Aleksanderhilf, Kreis Odessa nach dem Warthegau 1944. Heimatbuch der Deutschen aus Russland. Stuttgart, LMDR e. V., 1966, S. 43-48.

8. Bosch A. Das Drama der Selzer am Dnjester. URL: http://www.russianroots.ca/images/rrstory6.pdf (accessed 11 June 2019).

9. Bosch A., Lingor J. Entstehung, Entwicklung und Auflösung der deutschen Kolonien am Schwarzen Meer am Beispiel von Kandel von 1808 bis 1944. Stuttgart, Landsmannschhaft der Dt. aus Russland, 1990. 573 S.

10. Braun G. Auszug eines Briefes, geschrieben im April 1944 aus Turnu-Severin/Rumänien, der letzten Verpflegungsstation des Südtrecks aus Transnistrien. Heimatbuch der Deutschen aus Russland. Stuttgart, LMDRe. V., 1966, S. 49-51. 
11. Fernschreiben Greiser, Himmler, Greifelt, Lorenz, 30. März-02. April 1944: Stand der Transnistrien-Umsiedlung, Zusicherung RFSS für Greiser, dass Russlanddeutsche endgültig im Wartheland verbleiben; Unterstellung der Ansiedlungsstäbe unter die Landräte. Archiv des Instituts für Zeitgeschichte - München (IfZ-Archiv), MA 303/1, Bl. 9264-9274.

12. Fleischhauer I. Das Dritte Reich und die Deutschen in der Sowjetunion. Stuttgart, Deutsche Verlags-Anstalt, 1983.257 S.

13. Geheimes Fernschreiben Hoffmeyer, RFSS, 26. März 1944; Besprechung Hoffmeyer mit General Madare, stellvertretender Chef des rumänischen Generalstab betr. Rückführung der Deutschen aus Transnistrien. IfZ-Archiv, MA 303/1, B1. 9275-9279.

14. Geheimes Fernschreiben Lorenz, Hildebrandt, Warlimont, Hoffimeyer an RFSS, 19. Januar-22. Mai 1944: Durchmarsch des Nord- und Südtrecks aus Transnistrien durch Bulgarien, Rumänien und Ungarn; anfängliche Einwände Marschall Antonescu gegen Durchmarsch durch Dobrudscha. IfZ-Archiv, MA 303/1, Bl. 9232-9257.

15. Geheime Fernschreiben Warlimont, Lorenz, Hoffmeyer u.a., 12. März-12. April 1944: Abmarschbefehl für deutsche Volksgruppe Transnistrien infolge militärischer Lage am 12. März 1944; Auffangräume, Grenzübergänge, Transportlage, Donauschiffe und Eisenbahnzüge der Wehrmacht; Versorgungsschwierigkeiten. IfZ-Archiv, MA 303/1, B1. 9280-9292.

16. Geheimes Rundschreiben Generalstab des Heeres, 13. April 1944: Kompetenzen, Transport- und Verpflegungsfragen bei Abschub Volksdeutscher aus Nordrumänien. IfZ-Archiv, MA 303/1, B1. 9258-9260.

17. Hoffmann R. Das Ende der volksdeutschen Siedlungen in "Trarisnistrien" im Jahre 1944. Aus der Arbeit des Bundesarhivs. Boppard a. Rh., 1977, S. 447-453.

18. Hornbacher W. Removal from the Homeland: A Surviving Eyewitness Documentary Report on the Evacuation of Ethnic Germans from the Black Sea Region of Ukraine to Germany in Early 1944 (Part I). Heritage Review, 2008, vol. 38, no. 1 (March), pp. 8-38.

19. Kuck G. Der Große Treck 1944. Heimatbuch der Deutschen aus Russland. Stuttgart, LMDR e. V., 2003, S. 169-174.

20. Malsam M. Unser Weg vom Schwarzen Meer über den Warthegau an die Petschora. Heimatbuch der Deutschen aus Russland. Stuttgart, LMDR e. V., 1992-1994, S. 165-175.

21. Militärbefehlshaber Südost/Oberquartier: KTB vom 01. Januar 1944 - 30. Juni 1944; Eintragungen über Ausrüstung des Serbischen Freiwilligenkorps, der serbischen Staatswache, der sogenannten "Vertrags-Cetniks" und die deutschen Truppen mit Waffen und Munition, Versorgung deutscher Flüchtlingstransporte aus Transnistrien. IfZ-Archiv, MA 690, B1. 888-910.

22. Monatsbericht, Volksdeutsche, Mittelstelle, Amt VII, Dezember 1943. Bundesarchiv Berlin, R 59/68, B1. 2-4.

23. Monatsbericht, Volksdeutsche Mittelstelle, Amt VII, Januar 1944. Bundesarchiv Berlin, R 59/68, Bl. 5-8.

24. Monatsbericht, Volksdeutsche Mittelstelle, Amt VII, Februar 1944. Bundesarchiv Berlin, R 59/68, Bl. 11-12.

25. Monatsbericht, Volksdeutsche Mittelstelle, Amt VII, März 1944. Bundesarchiv Berlin, R 59/68, Bl. 13-17.

26. Peterreins G. Unsere Rückkehr nach Deutschland. URL: http://www.blackseagr.org/pdfs/ gertrudes_diary-german.pdf (accessed 8 June 2019).

27. Schwindt W., Schäfer V., Stephan E. Der siebte Treck. Heimatbuch der Deutschen aus Russland. Stuttgart, LMDR e. V., 2004, S. 6-28.

28. Völkl E. Transnistrien und Odessa (19411944). Regensburg, 1996. $124 \mathrm{~S}$.

29. Zeugenvernehmung von Walter Paul Vahldieck, Hamburg, den 27. Mai 1963. BundesarchivAußenstelle, Ludwigsburg, B 162/2302, B1. 229-251.

\section{Information About the Author}

Vladimir L. Martynenko, Candidate of Sciences (History), Doctoral Student, M.S. Hrushevsky Institute of Ukrainian Archeography and Source Studies of the National Academy of Sciences of Ukraine, Trekhsvyatitelskaya St., 4, 02000 Kiev, Ukraine, traum1983@gmail.com, https://orcid.org/0000-0003-4563-6347

\section{Информация об авторе}

Владимир Леонидович Мартыненко, кандидат исторических наук, докторант, Институт украинской археографии и источниковедения им. М.С. Грушевского Национальной академии наук Украины, ул. Трехсвятительская, 4, 02000 г. Киев, Украина, traum1983@gmail.com, https://orcid.org/0000-0003-4563-6347 